\title{
Repetitive noxious stimuli to the peripheral nerves enhancing activity of reticular formation neurons in the rat
}

\author{
Lisa Watanabe, Taiko Kitamura, and Jinzo Yamada \\ Department of Anatomy, Tokyo Medical University, Tokyo, Japan
}

[Received 13 June 2002, Accepted 19 July 2002]

\begin{abstract}
Neurons in the reticular formation (RF) of the brainstem are thought to participate in the transmission of nociceptive information, because they receive fibers of the spinothalamic tract. However, the role of RF for the pain mechanism remained to be studied. In the present study, extracellular single-unit activities were recorded from RF of the medulla oblongata elicited by mechanical and electrical noxious stimuli to either hind limb of anesthetized rats.

Single-spike and multiple-spikes responding to single electrical stimulation were recorded in RF. Multiplespikes were grouped into the following three types from the number of spikes and the latency of each spike. Type I had two to four spikes, and the latency of each spike was not constant. Type II had three to six spikes, and the latency of the first spike was constant. Type III had five to eight spikes, and the latency of each of first three spikes was constant.

Noxious informations via A $\delta$ - and C-fiber reached to laminae V-VIII and laminae I-II, respectively, of the spinal dorsal horn. Moreover, there were lamina V neurons projecting to lamina III-IV, and lamina III-IV neurons projecting to lamina I-II. The presence of three types suggests that informations from various cells of origin of spinoreticular tract converged on a single neuron of RF. Furthermore, the presence of three types suggests that repetitive electrical stimuli activate various-closed circuits between the RF regions, because each of the RF regions of midbrain, pons and medulla oblongata connected reciprocally. Considering that RF receives and projects ascending and descending fibers in the brain and the spinal cord and that RF has reciprocal connections among ipsilateral and contralateral regions, we assumed that multiple spikes of RF contribute continuously to facilitating pain perception.
\end{abstract}

Key words: reticular formation, noxious stimulation, multiple spikes

繰り返し侵害刺激に対して反応頻度が増加する網様体細胞

渡辺 リサ・北村 泰子 ・ 山田 仁三

〔東京医科大学解剖学第二講座〕 


\section{はじめに}

痛覚情報は脊髄後角でニューロンを変えた後，対 側の脊髄前側索外側部を上行する新脊髄視床路と, 前側索内側部を上行する旧脊髄視床路および宜髄網 様体路に分かれて脳幹に至る。このうち，旧脊髄視 床路と脊髄網様体路は網様体と密接なかかわりを持 つ. 新脊髄視床路は痛みの弁別系に関与しており, 旧脊髄視床路や脊髄網様体路は痛みの情動系に関与 している。旧脊髄視床路は脳幹網様体に側枝を出し ながら上行し，視床髄板内核群で中継され，体性感 覚野と大脳辺縁系に投射する。春髄網様体路は脳幹 網様体で中継され，髄板内核群および視床下部に投 射する。新脊髄視床路は脊髄の主に対側を上行する が，脊髄網様体路は同側性優位で，両側性に上行す る ${ }^{17)}$.

脳幹網様体は中脳, 橋, 延髄にかけて発達し, こ れらの領域で広いネットワークを形成している。網 様体は神経細胞体が散在した境界不明瞭な核集団で あり，神経細胞体の間を神経線維が様々な方向に走 行して網状構造を形成する。機能としては覚醒や運 動・感覚の制御, 呼吸, 循環系の制御など生命維持 に重要な機能に影響していることが知られてい る 1,10,12). しかし, 痛覚機能と網様体の関係につい ての研究は少ない。

痛覚情報を伝える旧脊髄視床路は網様体において ニューロンを乗り換えることから，網様体は痛覚情 報に対し何らかの機能を有すると考えられるが，そ の詳細は明らかではない。そこで我々は，痛みに対 する網様体の生理機能を解明することを目的とし， 麻酔下のラットにおいて侵害刺激に対する延髄網様 体の細胞外単一神経活動（unit）を記録し，分析し た。

\section{方 法}

実験にはWistar 系成熟ラット26 匹（䧳雄, 体重 186 ～ $410 \mathrm{~g}$ ）を用いた。ペントバルビタールを $35 \mathrm{mg} / \mathrm{kg}$ の用量で腹腔内に注射し，以後実験終了時 まで麻酔状態を保つため必要に応じてペントバルビ タールを $15 \mathrm{mg} / \mathrm{kg}$ の用量で腹腔内注射した。動物の 頭部を脳定位固定装置に固定し，局所麻酔剂の塩酸 リドカイン $(10 \mathrm{mg} / \mathrm{m} l)$ を約 $0.5 \mathrm{~m} l$ 頭皮下に注射し た後，頭頂を正中切開した。脳図譜 14,18）に従い,
歯科用ドリルで interaural line $(0.0 \mathrm{~mm})$ から尾方 $3.0 \mathrm{~mm}$ の間で，正中線から外側方 $2.0 \mathrm{~mm}$ の範囲で 頭蓋骨に穴をあけた。実験中は体温保持装置で動物 の体温を $36^{\circ} \mathrm{C}$ に維持し，心拍数をモニターした。 動物には刺激電極を左右の大腿部皮下にそれぞれ取 り付けた。

手術終了後，記録電極をマイクロマニュピュレー ターを用いて脳内に挿入し，延髄網様体巨大細胞核 の unit を探索した．記録電極にはタングステン電極 $(\phi 0.4 \mathrm{~mm}, 0.65 \sim 1.0 \mathrm{M} \Omega)$ を 7 例の動物で使用し， ガラス管微小電極を 19 例で用いた。ガラス管には $2.5 \%$ biotinylated dextran amine (BDA)，3M KCl を含 む $0.05 \mathrm{M}$ リン酸緩衝液または $0.9 \%$ 塩化ナトリウム 水溶液を充填し，2〜 $5 \mathrm{M} \Omega$ の抵抗を持つものを使 用した。電気刺激強度は $0.1 \mathrm{~mA}$ (1.0 msec duration) から徐々に強くしていき，下肢の twitching が見られ た強度以上に設定した。電気刺激は unitの記録側と 同側の下肢に与えた.さらに, 機械的侵害刺激 (pinch) および機械的非侵害刺激（touch, press）を，刺激電 極が刺入された部位に対応する皮膚およびその部位 と反対側の皮膚に行った。記録電極からの電気信号 は微小電極用増幅器と生体電気用増幅器で増幅し, その増幅周波数帯域は $150 \mathrm{~Hz}$ から $10 \mathrm{kHz}$ に設定し た。電気現象はデータレコーダーでデジタルオー ディオテープに記録するか, PowerLabを用いて Macintoshに記録した。記録されたデータは後に， 各々の電気刺激に対するスパイク潜時を計測しグラ フ化した。 さらに，それぞれの unitで50 回の刺激 における潜時の平均 \pm 標準偏差を求め統計的処理を 行った.

実験終了後, 14 匹の動物では unit が記録された部 位にBDA を注入した（0.4〜 $5 \mu \mathrm{A}$ の直流電流を7 秒 $\mathrm{ON} ， 7$ 秒 $\mathrm{OFF}$ で 20 〜 40 分). また， 4 匹の動物 ではタングステン電極を用いて $20 \mu \mathrm{A}$ で 20 秒間通 電し記録部位を凝固した. 8 匹については記録部位 の同定を行わなかった。

BDA を注入した動物では 7 ～ 18 日の生存期間を おいた後，生理食塩水 $300 \mathrm{ml} ， 4 \%$ パラフォルムア ルデヒド-リン酸緩衝液（pH 7.4） $300 \mathrm{ml}$ で潅流し 脳を取り出して同固定液中で 1 日固定した後，30\% サッカロースを含むリン酸緩衝液に 1 日入れた。そ の後脳の $50 \mu \mathrm{m}$ の連続凍結前頭断切片を作製し, $\mathrm{ABC}$ 法で反応させた後 diaminobenzidine で呈色反応 


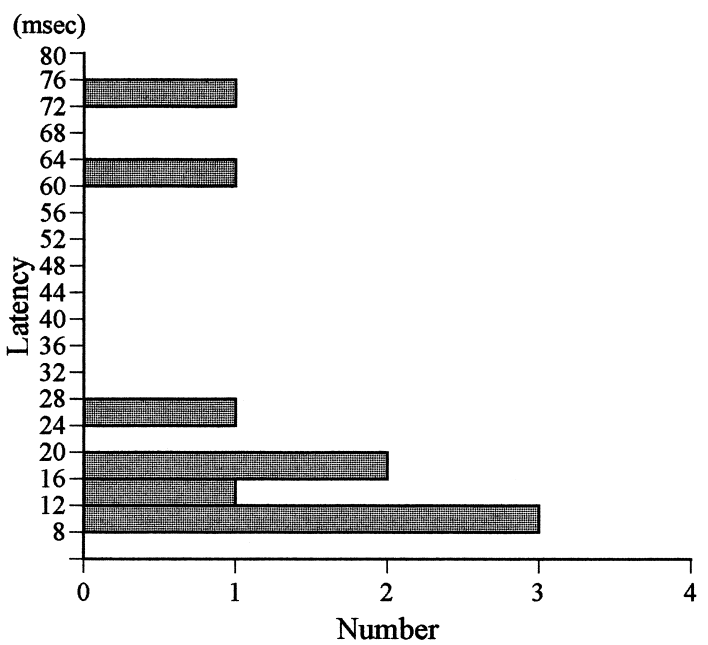

Fig. 1 Histogram of averaged latencies of unit with single spike. These latencies were divided into a range of $8 \sim$ $25 \mathrm{msec}$ and $60 \sim 75 \mathrm{msec}$.

させた. 切片は $1 / 4$ をニュートラルレッドで後染色 をし，注入部位を調べた.タングステン電極で通電 した動物は生理食塩水 $300 \mathrm{~m} l, 10 \%$ ホルマリン $300 \mathrm{ml}$ で潅流し脳を取り出した後, 30\% サッカロー スを含むホルマリンに 1 日入れた。 その後下位脳幹 の $50 \mu \mathrm{m}$ 連続凍結前頭断切片を作製し，ニュートラ ルレッドで染色をして傷の部位を調べた。

\section{結果}

本研究において，末梢の電気刺激および機械的侵 害刺激の両刺激に反応した unitを 70 個記録した。 これらのうち54 個の unitで自発放電が見られた。 自発放電を持つ unitのうちの 12 個は末梢の電気刺 激に対して自発放電頻度が数秒間にわたる変化を示
A

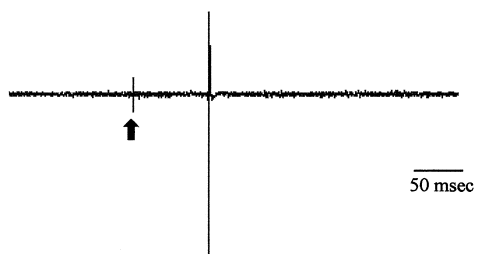

B

C


Fig. 2 Unit with single spike responding to single electrical stimulation. A: Single spike was evoked by electrical stimulation (arrow). B: Unit discharge in response to mechanical noxious stimulation (pinch, bar). C: Unit discharge in response to mechanical non-noxious stimulation (pressure, bar). Both stimuli elicited low frequency discharge. This unit did not exhibit the spontaneous discharge.

し（頻度上昇: $n=8$, 頻度下降: $n=4)$ 各スパイク潜時 の計測ができなかったため, 本研究では電気刺激に 対してスパイク応答を示した unit $(n=58)$ について の所見を述べる。これらの unit の応答様式は，単発 の刺激に対して単発スパイク応答したものと，2 か ら 10 発の複数のスパイク応答を示したものであっ た。

Table 1 Spontaneous activity and response for non-noxious stimulation according to each unit type

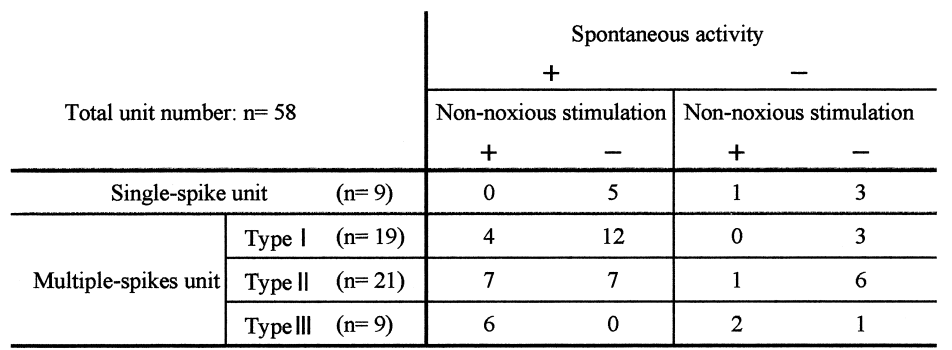

All unit responded to mechanical noxious stimulation. Spontaneous activity exhibited: +, did not exhibit: Unit responded to non-noxious stimulation: + , did not exhibit: - . 


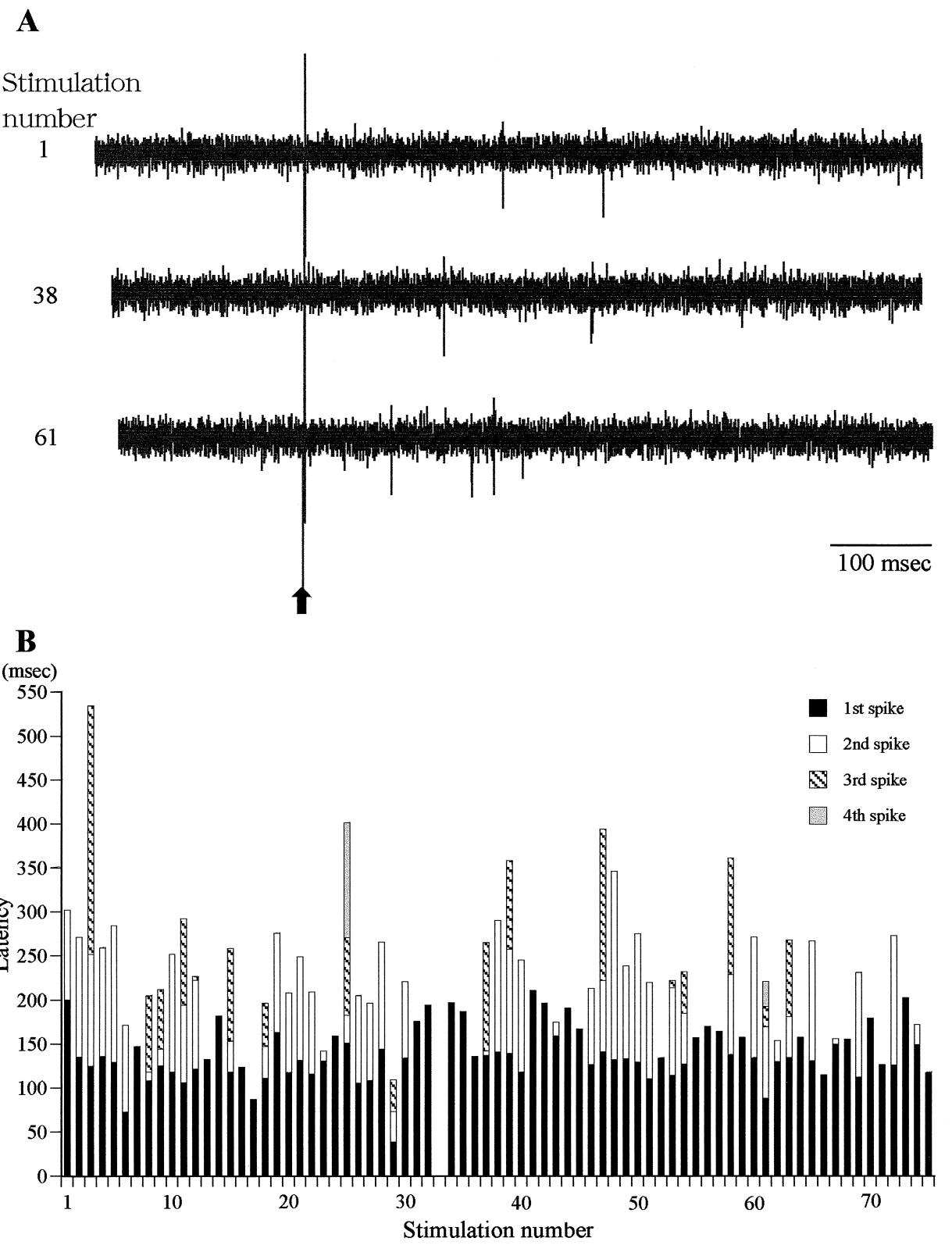

Fig. 3 Typical Type I neuron responses to electrical stimulation. A: Extracellular recording of Type I neuron in responding single electrical stimulation (arrow). The stimulus number is shown on the left site. B: Graph of the number of the spikes and the latency in response to electrical stimulation. The latency of each spike was irregular (averaged total latency of first spike: $138.64 \pm 33.54 \mathrm{msec})$.

電気刺激に対して単発スパイク応答を示した unit $(\mathrm{n}=9)$ では, 各々の unitの潜時の平均は $8 \mathrm{msec}$ か ら $75 \mathrm{msec}$ の範囲にあった (Fig. 1). $75 \mathrm{msec}$ の潜時 を持つ unit（Fig. 2A）では機械的侵害刺激への応答
に加えて（Fig. 2B），下肢を押したときの非侵害刺 激に対しても応答を示した（Fig. 2C)。この unitで は自発放電は見られなかった。残りの8 個について は非侵害刺激に対して応答せず，このうち 5 個の 
$\mathbf{A}$

Fig. 4 Type I neuron responses to mechanical stimulation. A: Unit discharge in response to mechanical noxious stimulation (pinch, bar). B: Unit discharge in response to mechanical non-noxious stimulation (touch, bar). This neuron increased in firing rate during both noxious pinching and non-noxious stimulation.

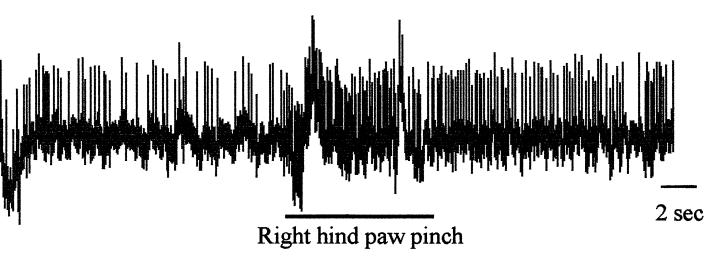

B

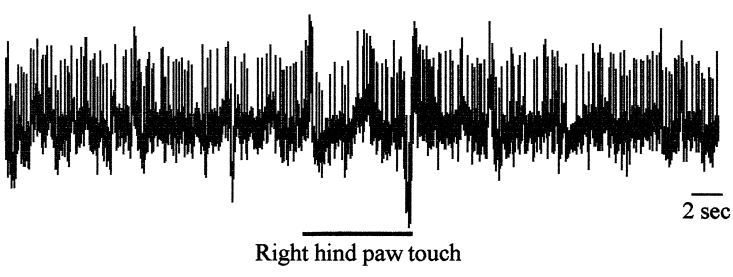

unit で自発放電が見られ，3 個では見られなかった

から $36.40 \mathrm{msec}$ までの範囲に分散していた（26.80土 (Table 1).

複数のスパイク応答を示した unit $(\mathrm{n}=49)$ は，そ のスパイク発射様式から以下の 3 つのタイプに分類 した。

\section{Type I}

Type I に分類した unit（n=19）は，刺激に対する スパイク応答の数にばらつきが見られ，その潜時も 一定してはいなかった。 Type Iでは, 最大 4 発のス パイク応答が見られた. Fig. 3 の unitでは, 最初の スパイク潜時は $38.90 \mathrm{msec}$ から $210.65 \mathrm{msec}$ までの 範囲に分散していた（平均潜時 $138.64 \pm 33.54 \mathrm{msec}$ ). この unitでは最大 4 発のスパイク応答が見られた。

Type I では 19 個中 4 個の unit が下肢を触れた非 侵害刺激に対しても応答を示し，4個全てに自発放 電が見られた。一例として，侵害刺激に対しての応 答（Fig. 4A）と非侵害刺激に対しての応答（Fig.4B） を示した。両機械的刺激に応答して, 自発放電頻度 の増加が見られた。なお，非侵害刺激に応答しな かった 15 個の unitのうち 12 個で自発放電が見ら れ，3個で見られなかった（Table 1).

\section{Type II}

Type II の unit（n=21）は，最初のスパイク潜時は 一定であるが 2 発目以降の潜時が不規則なものであ る. Type II では，最大 10 発のスパイク応答が見られ た.Fig. 5 に示した unitでは最初のスパイク潜時は $14.72 \pm 1.68 \mathrm{msec}$ であった。 2 発目の潜時は $15.90 \mathrm{msec}$ $4.90 \mathrm{msec})$.この unit では最大 6 発のスパイク応答 を示した。

Type II では 21 個中 8 個の unitが下肢を触れた非 侵害刺激にも応答を示し，これら 8 個の unitのうち 7 個で自発放電が見られた。なお，非侵害刺激に応 答しなかった 13 個中 7 個の unit で自発放電が見ら れ，6個で見られなかった（Table 1)。

\section{Type III}

Type III に分類された unit $(\mathrm{n}=9)$ は，最初の数発 のスパイク潜時が一定であるものである. Type III の unitでは, 最大 10 発のスパイク応答が見られた. Fig. 6 に示した unit では 1 から 3 発目までのスパイ ク潜時が一定しており，それぞれ $13.01 \pm 0.62 \mathrm{msec}$, $16.71 \pm 1.78 \mathrm{msec}, 23.56 \pm 1.91 \mathrm{msec}$ であった。この unit では最大 8 発のスパイク応答が見られた.

Type III では 9 個中 8 個の unit が下肢を触れた非 侵害刺激にも応答を示し，これら 8 個のうち 6 個の unit で自発放電が見られ，2 個では見られなかった。 なお，非侵害刺激に応答を示さなかった 1 個につい ては自発放電は見られなかった（Table 1).

記録された unitのタイプ別にBDA 注入部位およ び電気凝固部位を, 大細胞網様体抢よびその周辺に 図示した (Fig. 7). Type III が記録された場所は組 織学的に同定しなかったが, 各夕イプの unit は大細 胞網様核に広く分布していた。 

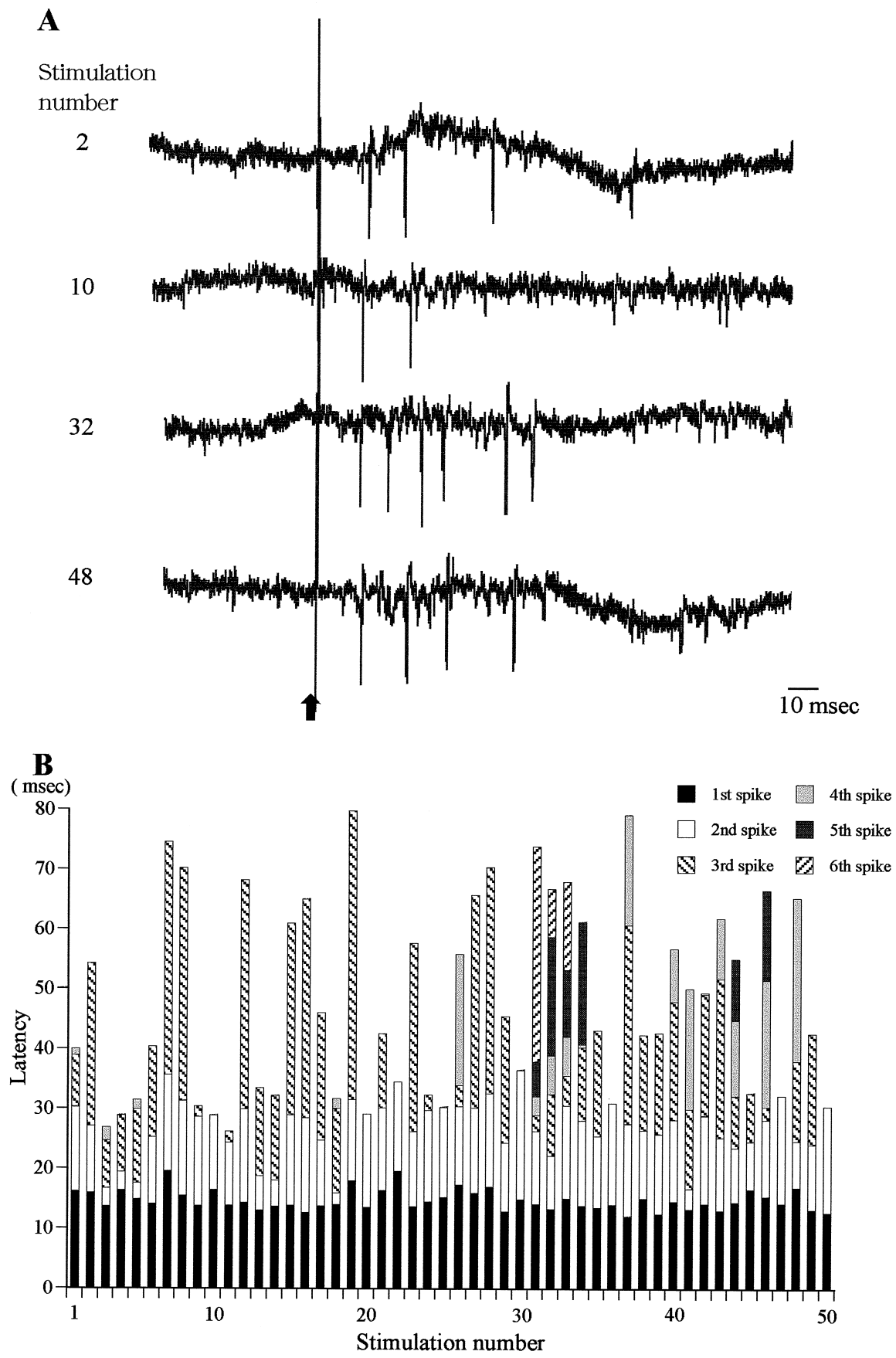

Fig. 5 Typical Type II neuron responses to electrical stimulation. A: Extracellular recording of Type II neuron in responding single electrical stimulation (arrow). The stimulus number is shown on the left site. B: Graph of the number of the spikes and the latency in response to electrical stimulation. The latency of first spike was constant (averaged total latency: $14.72 \pm 1.68 \mathrm{msec})$. 


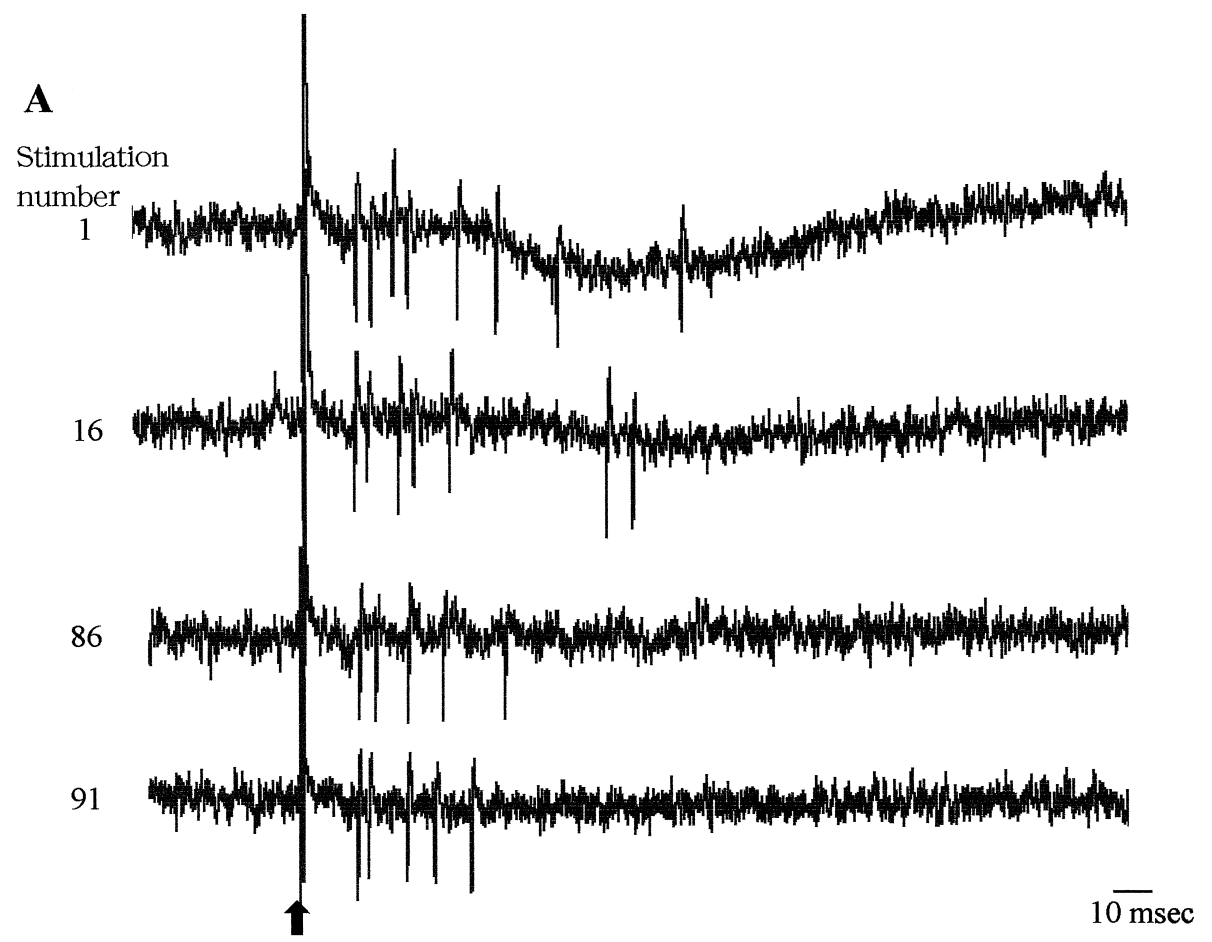

B



Fig. 6 Typical Type III neuron responses to electrical stimulation. A: Extracellular recording of Type III neuron in responding single electrical stimulation (arrow). The stimulus number is shown on the left site. B: Graph of the number of the spikes and the latency in response to electrical stimulation. The latency of each of first three spikes were constant (averaged total latency: $13.01 \pm 0.62 \mathrm{msec}, 16.71 \pm 1.78 \mathrm{msec}, 23.56 \pm 1.91 \mathrm{msec}$, respectively). 


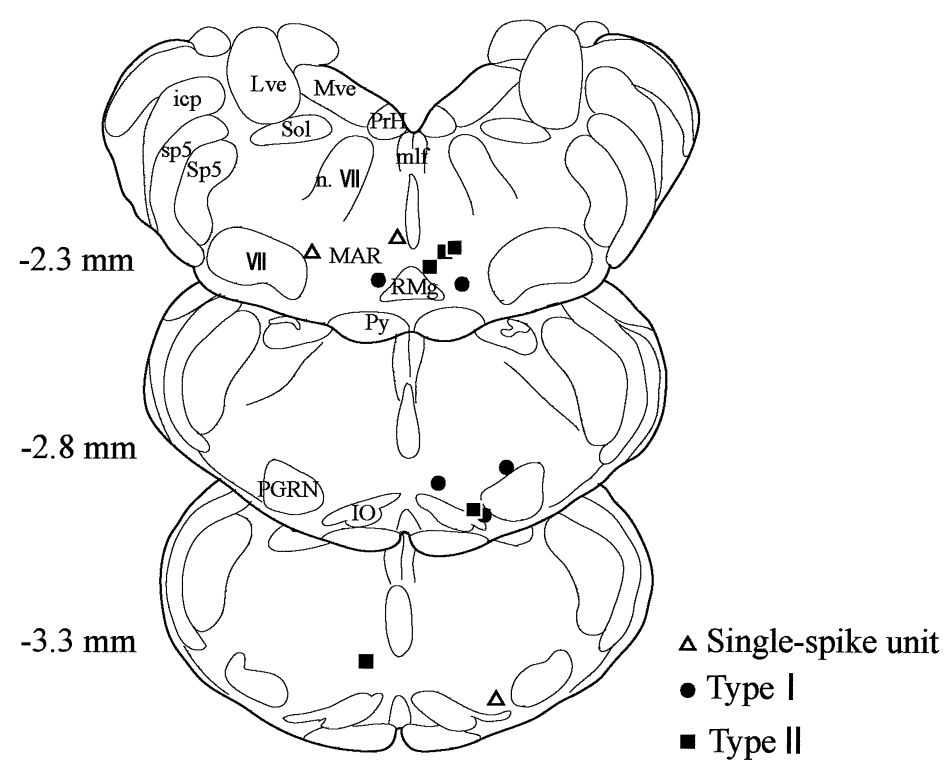

Fig. 7 Distribution of BDA injection and current injury sites in RF. Single spike-responded neurons were symbolized by triangles, Type I by filled circles and Type II by squares. Type III was not identified histologically. The numbers referred to the location of the section relative to interaural zero. VII: facial nucleus, icp: inferior cerebellar pedunculus, IO: inferior oliva, Lve: lateral vestibular nucleus, mlf: medial longitudinal fasciculus, MAR: magnocellular reticular nucleus, Mve: medial vestibular nucleus, n. VII: facial nerve, PrH: prepositus hypoglossal nucleus, py: pyramidal tract, RMg: raphe magnus, Sol: nucleus of solitary tract, sp5: spinal tract of the trigeminal nerve, Sp5: nucleus of the spinal tract of the trigeminal nerve.

\section{考察}

春髄網様体路は同側性優位であるので, 本研究で は記録部位に対し同側性の刺激を行った。末梢の電 気刺激に対して単発スパイク応答を示した unitと複 数スパイク応答を示した unit が得られ，複数スパイ ク応答をした unit はその応答様式の傾向から 3 つの タイプにグループ分けした。多くの unitにおいては 非侵害刺激に応答していなくてもピンチによる機械 的侵害刺激に応答し, かつ電気刺激を与えた時にも 応答を示したことから, 今回行った電気刺激は侵害 刺激とみなされる。

末梢における求心性侵害受容線維は, 伝導速度の 早い機械的侵害刺激に応答する $\mathrm{A} \delta$ 線維と, 伝導速 度が遅く機械的侵害刺激のみならず温度・化学刺激 にも応答する C 線維である。これらの線維によって 脊髄に伝導された侵害情報は, 脊髄後角で少なくと も1つのニューロンを介してから上行性に伝わる. 本実験で行った刺激は $\mathrm{A} \delta$ 線維, $\mathrm{C}$ 線維を選択的に
刺激しておらず, 複数の両線維が刺激されていると 思われるが，同条件下で末梢の単発刺激に単発スパ イク応答をした unit と複数スパイク応答を示した unit が記録された。これらのことは，春髄内で情報 を複雑に交換した後, 侵害情報が特定の網様体細胞 に収束することを示唆している.さらに網様体の中 では多くの相互結合を有することから, 網様体内で の情報交換後, 特定の網様体細胞に収束することも 示唆される.

後根から脊䯣後角へ入った各線維は，A $\delta$ 線維は Rexed $^{15)}$ のV 層を中心にVI層およびVIII 層に，C 線維は主に I-II 層に投射し9)，I-II 層からの線維は 介在細胞を通してV 層およびVII 層に投射する。さ らに V 層から III-IV 層へ， III-IV 層から I-II 層への 結合もある。脊髄網様体路は主にV 層およびVII 層 を起始細胞とし，同側性優位で網様体に終始する 2$)$. さらに I, V, VII 層からの線維は交叉して旧脊髄視床 路 3) となり, それは上行しながら網様体に側枝を 出しながら視床髄板内核へ投射する $6,7,21)$. また主 
に V-VII 層から交叉した脊䯣網様体路も存在する ${ }^{5)}$. 脳幹網様体では, 延髄, 橋, 中脳の各領域において 互いに線維結合を有し閉鎖回路を形成している ${ }^{20)}$. 以上のような線維結合を背景にして, 本研究でのス パイク応答の発生を以下に考察する。

各線維の伝達速度は A $\delta$ 線維では $10 \sim 30 \mathrm{~m} / \mathrm{sec}$, C 線維では $0.4 \sim 2 \mathrm{~m} / \mathrm{sec}$ であるので, 未梢から脊髄 までの潜時は A $\delta$ 線維では拈よそ3〜 $10 \mathrm{msec}, \mathrm{C}$ 線 維ではおよそ 50 ～ $250 \mathrm{msec}$ である. 本実験での結 果では, 単発スパイク応答した unit はその潜時で分 けると 8 〜 $25 \mathrm{msec}$ の範囲の潜時を持つものと 60 〜 $75 \mathrm{msec}$ の範囲のものになる．末梢から脊髄までの 潜時で推測すると前者が A $\delta$ 線維由来, 後者が伝導 速度の速い C 線維由来であると考えられる. 脊髄か ら記録部位である網様体までの経路は不明であるた め, 各潜時の長さから以下のように考えた。最も潜 時の短いものは後角に投射したA $\delta$ 線維から 2 次 ニューロンを介して同側性に網様体に結合している ものと思われる。また， A $\delta$ 線維由来のスパイクの 中でも潜時に差があるのは，脊髄内でいくつか介在 ニューロンを介して投射したためであろう.さらに， 網様体内で閉鎖回路を経て伝導された可能性もあ り，これらの組み合わせによって潜時に差が生じる であろう。C 線維の潜時の差についても，A $\delta$ 線維 と同様な組み合わせが成り立つものと考えられる. 単発スパイク応答は, 末梢の刺激によって活性化さ れたいくつかの脊髄後角細胞のうち, 単独のニュー ロンを起始細胞としてその軸索と結合している網様 体細胞で誘発されたものと思われる.

複数のスパイク応答を持つものでは, 短い潜時の ものでは $14.72 \mathrm{msec}$ (Type II), $13.01 \mathrm{msec}$ (Type III) であった。これらは上記のように，A $\delta$ 線維から脊 髄後角細胞を介して同側性に網様体に結合した線維 からのスパイクであると思われる. 次に $16.71 \mathrm{msec}$ (Type III 2 発目), $23.56 \mathrm{msec}$ (Type III 3 発目) で あるが，これらは脊髄内で経由した介在ニューロン の数の違いによる差であるか, 網様体内での閉鎖回 路の経路の違いであるか, またはその両方が組み合 わされたものかは判断できないが, 以上の可能性が 考えられる。

Type Iでは, 最初のスパイク潜時は 38.90〜 $210.65 \mathrm{msec}$ までに分散していた。一部に A $\delta$ 線維由 来のスパイクもあるのであろうが，ほとんどのスパ
イク潜時は $100 \mathrm{msec}$ 以上であり（Fig. 3)，これらは 末梢から脊髄までの潜時で推測すると C 線維由来で あると考えられる。C 線維が投射した I-II 層の 2 次 ニューロンの線維，また介在細胞を通してV 層に 投射した細胞からの線維は交叉性が多く, 対側から の情報が網様体内の閉鎖回路を経由したため, 潜時 が長いと考えられる. 単発スパイク応答の unit では 潜時は $60 \sim 70 \mathrm{msec}$ の範囲にあり，上記 Type I の $\mathrm{C}$ 線維由来のスパイク潜時と比較すると短いため, C 線維が投射した I-II 層から同側性に線維結合した 網様体細胞からのスパイク応答であろうか.

これらの複数スパイク応答は，末梢刺激によって 活性化された脊髄後角細胞のうちの複数のニューロ ンが起始細胞となり, 複数の上行性線維が 1 つの網 様体細胞に収束したことにより誘発されたものと考 えられる。

今回記録された細胞では, 侵害刺激のみではなく, 機械的刺激にも応答を示したものもみられた. Leung と Mason は大細胞網様核に見られる ON cell と OFF cell が侵害刺激に対して 10 秒以上にわたる応答を示 すことを報告した ${ }^{8,11)}$. 彼らはこれらの細胞が無害 な体性感覚および聴覚の刺激に応答するという Oliveras らの所見 ${ }^{13)}$ などから，ON および OFF 細 胞は侵害・非侵害的などの数多くの生理学的な入力 に対して応答して侵害受容伝達を修飾することを示 唆した。今回我々が延髄網様体で得た所見は, 彼ら の所見を支持しているように考えられる.

網様体の主要な下行性線維は脊髄へ投射するもの であり ${ }^{4)}$, 大細胞網様核の活性化は下行性疼痛抑制 を促進することから ${ }^{16,19)}$, 網様体細胞からの情報 は脊髄で鎮痛効果を持つ. 本実験では侵害刺激に対 し複数スパイク応答という興奮性の応答を示してお り，これが脊髄後角における侵害刺激のインパルス 通過を遮断する抑制作用に働くかどうかは本研究で は結論できない。しかし，末梢の刺激に対して網様 体細胞 が異なる応答を示すということ, およびその 網様体細胞が脊髄各層に投射線維を送ることを我々 は形態学的に観察している (未発表). 本研究での 網様体細胞の様々な応答は, 下行性疼痛抑制を複雑 にコントロールしていることを示唆している.

本研究で明らかにした網様体単一細胞が多数の侵 害情報を受けていることは発痛メカニズムの複雑さ を示している．網様体での機能の解明は疼痛に関す 
る理解の一助を担うであろう。今後，この領域で本 研究をもとにした更なる形態学的検討や薬理学的検 討を含めた研究が必要であろう.

\section{文献}

1) Blessing, W.W., The lower brainstem and bodily homeostasis, Oxford Univ. Press, New York, 1997, 575pp.

2) Chaouch, A., Menetrey, D., Binder, D. and Besson, J.M., Neurons at the origin of the medial component of the bulbopontine spinoreticular tract in the rat: an anatomical study using horseradish peroxidase retrograde transport, J. Comp. Neurol., 214 (1983) 309320.

3) Craig, A.D., Linington, A.J. and Kniffki, K.D., Cells of origin of spinothalamic tract projections to the medial and lateral thalamus in the cat, J. Comp. Neurol., 289 (1989) 568-585.

4) Holstege, G. and Kuypers, H.G., The anatomy of brain stem pathways to the spinal cord in cat, A labeled amino acid tracing study, Prog. Brain Res., 57 (1982) 145-175.

5) Kevetter, G.A., Haber, L.H., Yezierski, R.P., Chung, J.M., Martin, R.F. and Willis, W.D., Cells of origin of the spinoreticular tract in the monkey, J. Comp. Neurol., 207 (1982) 61-74.

6) Kevetter, G.A. and Willis, W.D., Spinothalamic cells in the rat lumbar cord with collaterals to the medullary reticular formation, Brain Res., 238 (1982) 181-185.

7) 北村泰子, 山田仁三, 痛覚伝導路の今日的課題, J. Neurosci. for pain research, 3 (2001) 5-10.

8) Leung, C.G. and Mason, P., Physiological survey of medullary raphe and magnocellular reticular neurons in the anesthetized rat, J. Neurophysiol., 80 (1998) 1630-1646.

9) MacMahon, S.B., Spinal mechanisms in somatic pain. In: Holden, A.V. (Ed.), The neurobiology of pain, Manchester Univ. Press, 1984, pp159-178.

10) Magoun, H.W. and Rhines, R., An inhibitory mechanism in the bulbar reticular formation, J. Neurophysiol.,
9 (1946) 165-171.

11) Mason, P., Contributions of the medullary raphe and ventromedial reticular region to pain modulation and other homeostatic functions, Апnи. Rev. Neurosci., 24, (2001) 737-777.

12) Moruzzi, G. and Magoun, H.W., Brain stem reticular formation and activation of the EEG, Electroencephalogr. Clin. Neurophysiol., 1 (1949) 455-473.

13) Oliveras, J. L., Vos, B., Martin, G. and Montagne, J., Electrophysiological properties of ventromedial medulla neurons in response to noxious and non-noxious stimuli in the awake, freely moving rat: a single-unit study, Brain Res., 486 (1989) 1-14.

14) Paxinos, G. and Watson, C., The rat brain in stereotaxic coordinates, Academic press, Sydney, 1982, 81pp.

15) Rexed, B., A cytoarchitectonic atlas of the spinal cord in the cat, J. Comp. Neurol., 100 (1954) 297379.

16) Sandkuhler, J. and Gebhart, G.F., Relative contributions of the nucleus raphe magnus and adjacent medullary reticular formation to the inhibition by stimulation in the periaqueductal gray of a spinal nociceptive reflex in the pentobarbital-anesthetized rat, Brain Res., 305 (1984) 77-87.

17) 佐藤孝雄, 久光正, 脳幹網様体と病態痛み, Cilnical Neurosci., 17 (1999) 67-69.

18) Swanson, L.W., Brain maps: Structure of the rat brain, Elsevier, Amsterdam, 1992, 240pp.

19) Urban, M.O. and Smith, D.J., Nuclei within the rostral ventromedial medulla mediating morphine antinociception from the periaqueductal gray, Brain Res., 652 (1994) 9-16.

20) Yamada, J., Sato, H., Kitamura, T. and Otani, K., The reticular formation in the pain system: a morphological study. In: Takagi, H., Oomura, Y., Ito, M. and Otsuka, M. (Eds.), Biowarning system in the brain, University of Tokyo press, Tokyo, 1988, pp31-42.

21）山田仁三，痛覚中枢はどこにあるのか: 生存と自 己表現のための知覚, 協同医書出版社, 東京, 2000, pp89-124. 